\title{
Granting of the Usufructuary Rights over Customary Land for Oil Palm Plantations in Nagari Inderapura of Pesisir Selatan Regency
}

\author{
Heroe Supriyanto; Kurnia Warman; Zefrizal Nurdin \\ Faculty of Law, Andalas University, Padang, Indonesia
}

http://dx.doi.org/10.18415/ijmmu.v6i5.1068

\begin{abstract}
The objectives of this study are to: 1) describe and explain the granting of oil palm plantation licensing which becomes usufructuary rights, 2) describe and explain the release of customary rights for the oil palm plantation business, and 3) describe and explain the granting and registration of usufructuary rights of oil palm plantation originating from customary rights. This study employs an empirical juridical approach. Granting of oil palm plantation business licensing occurs with the approval of the principle of oil palm plantation cultivation business, application for location permits and a letter from the Governor of the Level I Region of West Sumatra Province regarding licensing for land clearing for the oil palm plantation business. Currently, the release of customary rights for the oil palm plantation business in Nagari Inderapura is carried out using the custom of "diisi limbago dituang" method through consensus agreement with payment of silihjariah money to ninik mamak with a total land area of $\pm 11,930$ hectares. Granting and registration of usufructuary rights of oil palm plantations must be registered in the land book at the land office and must also advance the rights of local customary people. In this case, the main target of the use of customary land is to improve the welfare and prosperity of customary people. In addition, in agrarian reform, land redistribution is required to provide at least $20 \%$ (twenty percent) of the land area used for the local community.
\end{abstract}

Keywords: Granting; Usufructuary Rights; Oil Palm Plantation; Customary Land

\section{Introduction}

Customary rights of people customary law are recognized in Law No. 5 of 1960 concerning Basic Rules of Agrarian Principles (Fay \& Sirait, 2005). The concept of customary rights of people customary law in Indonesia is not found in the concept of western law because western law has an individual, person or institution established. ${ }^{1}$ Among the customary lands in West Sumatra, especially in Nagari Inderapura,

\footnotetext{
${ }^{1}$ Kurnia Warman, Agrarian Law in Compound People: The Dynamics of Interaction of Customary Law and State Law in West Sumatra, HuMa, Jakarta, 2010, page 39.
} 
there is a customary land of Nagari which is submitted by the ninik mamak to the government and investors to be used as structural rights of oil palm plantations (Tegnan, 2015).

The purpose of conducting plantations is intended to improve the welfare and prosperity of people, increase the country's foreign exchange resources, provide employment and business opportunities, increase production, productivity, quality, added value, competitiveness, and market share, increase and meet consumption needs and industrial raw materials in the country, provide protection to plantation and community businesses, optimally, responsibly and sustainably manage and develop plantation resources, and increase the utilization of estate services (von Benda-Beckmann \& von BendaBeckmann, 2013). The implementation of these plantations is based on the principles of sovereignty, independence, usefulness, sustainability of cohesiveness, togetherness, openness, efficiency-justice, local wisdom, and preservation of environmental functions. Understanding of plantations can be found in the provisions of Article 1 (number 1), Law No. 39 of 2014 concerning Plantation (Wibowo, 2016).

Thus, the customary rights used for the plantation business are exhausted. On the other hand, regional regulations want to return this customary land to its original position as explained in Article 14 of West Sumatra Regional Regulation No. 6 of 2008 concerning Customary Land and Its Utilization. In addition, internal land conflicts also occurred in Nagari Inderapura related to the customary land between the ninik mamak and the nephew about the advantages of the customary land of Nagari given by ninik mamak to the government and investors. ${ }^{2}$ Regarding this conflict, Article 23 of the Regulation of the Governor of West Sumatra No. 21 of 2012 concerning Guidelines and Procedures for Utilizing Customary Land for Investment states:

1. Disputes that occur in the use of customary land for investment are resolved by deliberation and consensus to reach agreement directly through negotiations.

2. In the event that consensus is not reached, dispute resolution as referred to in paragraph (1) can be carried out with the help of the Nagari government, KAN, LKAAM, District Head, local government, and other independent third parties as mediators to conduct dispute mediation.

3. In the event that mediation as referred to in paragraph (2) is not reached, dispute resolution can be carried out through arbitration in accordance with statutory provisions.

4. Dispute resolution as referred to in paragraph (1), paragraph (2) and paragraph (3) does not exclude the possibility for investors and customary land owners or authorities to settle their dispute through the local village court in accordance with statutory provisions.

\footnotetext{
${ }^{2}$ Information was obtained from the statement of leader of Nagari Indigenous Representative (KAN) of Inderapura.
} 


\section{Research Findings and Discussion}

Granting of Oil Palm Plantation Licensing Becoming Usufructuary Rights in Pesisir Selatan Regency

Regarding the granting of licensing of oil palm plantations which became usufructuary rights in the Pesisir Selatan Regency, in 1997, according to Kamisral Rangkayo Rajo Melayu: ${ }^{3}$ in that year, the company/ investor came to Nagari Inderapura with a ball pick-up system. It means that ninik mamak/ leader of Nagari Indigenous Representative (KAN) of Inderapura at that time saw the condition of the Inderapura area which was full of swampy and jungle areas which were not able to be managed by its customary peers at that time. In addition, starting from the aim of improving the welfare of local people, ninik mamak/ leader of Nagari Indigenous Representative (KAN) of Inderapura invited or invited the company to open a plantation business in the Inderapura area. With the intention of ninik mamak/ leader of Nagari Indigenous Representative (KAN) of Inderapura to open a plantation business, the first handover in 1997 occurred.

With the invitation from ninik mamak/ leader of Nagari Indigenous Representative (KAN) of Inderapura, in that year, the company/ investor on behalf of PT Incasi Raya took care of the process of managing ninik mamak/ leader of Nagari Indigenous Representative (KAN) of Inderapura and the Government Pesisir Selatan Regency. With the certificate issued Muara Sakai Village Office No. 05/2040/MS/XII/1996, it is true that there is a customary land of Nagari which is controlled by ninik mamak/ leader of Nagari Indigenous Representative (KAN) of Inderapura area of $\pm 6,760$ hectares located in Muara Sakai Village according to a statement letter dated December 301996.

Continuing this, PT Incasi Raya takes care of licensing for the use of the land. The company/ investor first takes care of principle licensing and location licensing based on letter No. HK.350/E5.54/01.97 concerning Approval in Principle of PT Incasi Raya's Oil Palm Plantation Cultivation in West Sumatra Province. Based on article 9 paragraph (4) Decree of the Minister of Agriculture No. 786/Kpts/KB.120/10/96 the implementation of development in the field of plantation cultivation business is approved with the following details:

$\begin{array}{ll}\text { Company Name } & : \text { PT INCASI RAYA } \\ \text { Plant Type } & : \text { Palm Oil } \\ \text { Areal Location (net) } & : 25,200 \text { hectares } \\ \text { Location } & : \text { Pancung Soal District } \\ & : \text { Pesisir Selatan Regency } \\ & : \text { West Sumatra Province }\end{array}$

Furthermore, PT Incasi Raya applied for a location permit. Based on the Decree of the Head of the Pesisir Selatan District Office No. 401/1452 / BPN-1996, the location permit at that time was granted for the needs of an oil palm plantation business for PT Incasi Raya located in Pancung Soal District with an area of $\pm 6,670$ hectares with the following conditions:

1. The acquisition of land must be carried out directly between the location permit holder and the authority over the rights through the release of the right of over the land by making the minutes of the release of the rights over the land before the Head of the Pesisir Selatan District Land Office with granting compensation in the form and amount of which is determined by consensus agreement.

2. Payment of compensation for land, plants or buildings on it is not justified to be carried out through intermediaries but directly.

\footnotetext{
${ }^{3}$ Kamisral Rangkayo Rajo Melayu, Ninik/Mamak Kerapatan Adat Nagari Inderapura in 1996, interview on September $31,2019$.
} 
3. The acquisition of land must be completed within 12 months from the date of stipulation.

4. Land acquisition should only be carried out in an area determined in the land location map.

5. Regarding land that has been acquired and acquired, the location permit holder has a usufructuary rights to the National Land Agency.

6. Related to the location of land included in the PT Sumber Surya Semesta forest tenure area, it requires that the previous location permit holder in conducting field activities to coordinate it first with the forest tenure right through the Forestry Regional Office in accordance with applicable laws and regulations.

7. The location permit holder is required to make a mark of land use or land footprint on the area that has been released accompanied by the maintenance of land and the environment including a plan to maintain a river bank (100 meters) as a protected area in accordance with Presidential Decree No. 32 of 1992.

8. In carrying out field activities, location permit holders are required to accommodate workers according to the needs of the company management of location permit holders.

9. The location permit holder is required to become a foster father in the form of a partnership through granting of oil palm seedlings credit, fertilizer credit, and technical guidance to local farmers who open the plantation area independently of the reserved location whose form of cooperation will be determined by the location permit holder, the farmers Village Unit Cooperatives and Level II Regional Government in accordance with applicable laws and regulations.

10. Location permits that have been granted cannot be transferred or traded to another party.

Based on a letter from the Governor of the First Level Region of West Sumatra Province, No. 525.26/024/Perek-97 regarding the Land Opening Permit, PT Incasi Raya in principle can approve the permit for clearing an area of $\pm 6,670$ hectares. With a number of granting processes for oil palm plantations to be used as oil palm usufructuary rights in Nagari Inderapura, in the process of granting these permits, the company does not meet the requirements to empower plantations owned by local people such as the opening of plasma-nucleus land which is also the rights of local people in implementing business activities in the area (Vel, J\& Bedner, 2015).

In theory of rights, the rights of local customary people have not been fulfilled in the absence of the opening of plasma nucleus estates for people. Rights are something inherent in humans in physical aspects as well as their existential aspects. Hans Kelsen mentioned that rights are so important that they require recognition and protection in official registers. Thus, the right can obtain a position in the law of people. As long as a right is not protected by legal regulations, this right is not yet a legal right.

In the case of a company that has obtained a plantation business license, in theory the company has obtained legal certainty in carrying out its business activities. The purpose of the law is nothing but to guarantee the realization of legal certainty. Legal certainty is realized by law which is only made a rule of law that is general. The general nature of the rule of law proves that the law does not aim to bring about justice or expediency, but merely for certainty. In this case, in carrying out its business activities, the company has obtained legal certainty to carry out structural rights for oil palm plantations. However, the company/ investor must not override any rights that can be obtained from the local customary people for the customary land managed by the company. 


\section{Release of Customary Rights for Oil Palm Plantation Business in Nagari Inderapura of Pesisir Selatan Regency}

With the desire of PT Incasi Raya Group to conduct business activities in Nagari Inderapura of Pancung Soal District of Pesisir Selatan Regency in the field of Oil Palm plantations, at that time, an agreement between PT Incasi Raya with ninik mamak/ leader of Nagari Indigenous Representative (KAN) of Inderapura to submit the customary land of Nagari Inderapura to be used as an Oil Palm Plantation Business in accordance with the Declaration of the Right to Over Land Release dated January 8, 1997, with payment of pension funds in the amount of IDR 236,600,000 (two rows thirty six million six hundred rupiah) with area of $\pm 6,670$ hectares. However, the agreement was not accompanied by the establishment of plasma plantations for local people. The handover of the customary land of Nagari Inderapura has taken place in three phases.

Based on the results of an interview with Kamisral Rangkayo Rajo Melayu (ninik mamak and also a caretaker of the Taqwa Farmers Group), the researcher obtained information that the wishes of his relatives about plasma formation of $\pm 3,000$ hectares had been fulfilled. It was divided into two locations: first, the location of the Taqwa Farmers Group with an area of $\pm 1,000$ hectares located in the Nagari Lopon of West Inderapura and second, the location of the Farmers Community Development Group \pm 2,000 hectares located on Mount Gesak Inderapura. Kamisral Rangkayo Rajo Melayu told researchers that the current area of the Taqwa Plasma Plantation is \pm 283 hectares. Then, in the Community Development Farmer Group, the results of the interview of researchers with Ujang Jambing ${ }^{4}$ found that the current area of Community Development Farmer Group is \pm 419 hectares. Similar to the two figures, the tonnage yield from the plasma estate is very minimal from the fairness compared to the area of land managed. The figures can conclude that there is no seriousness of the company in managing the plasma land when compared to the tonnage of the core land. Thus, debt repayments with the credit system have not been paid off and are also stalled.

A statement of agreement for the plasma area of $\pm 3,000$ hectares has only been fulfilled with a plasma area of \pm 702 hectares. In line with this, based on the agreement letter dated June 16, 2005, there was agreement between the names of the community, ninik mamak, community leaders, students, youth elements, members of Nagari Inderapura (first party) and legal manager of PT Incasi Raya (second party). The memorandum of agreement was: that the first party and the second party made changes (addendum) to the statement letter dated September 8, 1998 (which was legalized by a notary in Painan, about the plan to develop a core plasma plantation for the Inderapura community, which was previously written $\pm 3,000$ hectares was changed to 2,000 hectares and an area of 1,000 hectares, they have also agreed to exit the Core Plasma Plantation Development Program and are willing to create their own plasma plantations by obtaining credit for oil palm seedlings ready for planting from PT Incasi Raya, both of which will use a commercial credit pattern from Bank Mandiri. affidavit of agreement dated September 8, 1998, insofar as it relates to provisions that have not been amended, it remains in force and is an inseparable part of this statement of agreement.

The handover of this second phase that occurred in 2005 also did not discuss the designation of plantations for the community as well as that first phase. In statutory regulations, Article 22 of Law No. 18 of 2004 concerning Plantations explains that:

(1) Plantation companies enter into partnerships that are mutually beneficial, respectful, mutually responsible, mutually reinforcing and interdependent with farmers, employees and communities around the plantation.

\footnotetext{
${ }^{4}$ Ujang Jambing, Chairman of the Community Development Plasma Group, interview on September 1, 2019.
} 
(2) Plantation business partnership as referred to in paragraph (1), may be in the form of cooperation in the provision of production facilities, production, processing and marketing cooperation, transportation, operational cooperation, share ownership, and other supporting services.

(3) Further provisions regarding the pattern of plantation business partnerships as referred to in paragraph (2) are stipulated by the Minister.

The law explains that: Partnership provisions are intended to further improve the welfare of employees, planters and surrounding communities and to maintain the security, sustainability and integrity of the plantation business. Thus, in the agreement statement dated June 16, 2005, according to the researchers, it only included an amendment (addendum) from the agreement letter, which was previously $\pm 3,000$ land area changed to 2,000 hectares and the remaining 1,000 hectares were willing to make their own plasma plantations by getting credit for ready-to-plant oil palm seedlings from PT Incasi Raya.

Submission of the third phase that occurred in 2017 is the handover of the issue of excess land from the previous handover in 1997 and 2005 with a total land area of \pm 570 hectares in which the distribution is \pm 285 hectares to PT Incasi Raya and \pm 285 hectares of PT SAK. There is also no transfer of this third phase to discuss the existence of plantations for the community. So, the submission process since 1997 also still leaves problems until now with the non-fulfillment of some rights to people. In this case, some on behalf of the Inderapura Ministry of Labor, related to the information of the 2017 Nagari Inderapura customary land with a total area of 570 hectares of customary land, made claims on the land to be used or reused where the land has produced oil palm on the company's core land. Therefore, in the name of the sanakan kemenakan, the land can be re-intended in the interests of the community to become a smallholding for the local people.

In accordance with the aim of agrarian reform to reduce land ownership and ownership inequality in order to create justice and deal with agrarian disputes and conflicts, it also needs land redistribution. Land redistribution is the distribution of lands controlled by the state and has been confirmed to be the object of land reform given to smallholder farmers who have fulfilled the requirements aimed at improving the socio-economic conditions of the community, especially farmers, by carrying out fair and equitable distribution of land. farmer livelihood in the form of land. So that fair and equitable sharing of results can be achieved through the granting. Land redistribution must provide at least 20\% (twenty percent) of the total area of state land given to usufructuary rights holders in the process of granting, extending or renewing their rights to the people.

From the other side, the Regulation of the Governor of West Sumatra also regulates the use of customary land. The economic welfare of local people also requires community participation in investors with the principle of mutual benefit in the form of a lease agreement, profit sharing, share ownership, and other forms based on the principle of freedom of contract, according to the agreement. It is based on Article 7 of the Governor of West Sumatra Regulation No. 21 of 2012 concerning Guidelines and Procedures for Utilizing Customary Land for Investment.

Thus, it requires the participation of the local community in terms of business management for investment and using the custom of "adat diisi limbago dituang" method; in the form of compensation for land used directly. The agreement to release the customary land of the nagari for the oil palm plantation business between ninik mamak/ leader of Nagari Indigenous Representative (KAN) of Inderapura and PT Incasi Raya Group was made through payment of silihjarih money. That is certainly not in accordance with the amount of profits obtained/ gained by the company against the customary land of the nagari that has been managed by the company/ investor. Therefore, the rights of the customary people themselves 
here have not been fulfilled at all. Thus, the partnership pattern in the formation of plasma land or the participation of local customary people in investors is fair to meet the interests of customary people and as a problem solver to boost the community's economy.

The importance of the law is to take care of human rights and interests so that the law has the highest authority to determine human interests that need to be regulated and protected by law. Thus, economic protection for the community is necessary because some type of protection is related to businesses and the provision of an adequate income to meet the daily needs of the community and their families. Therefore, rights are interests that must be protected by the rule of law.

Granting and Registration of Usufructuary Rights for Oil Palm Plantation Originating from Customary Rights Nagari Inderapura of Pesisir Selatan Regency

In the case of granting and registration of usufructuary rights for oil palm plantations, the National Land Agency (BPN) as the party indicated in the management provides the widest possible opportunity for customary land holders/ authorities in this case ninik mamak/ leader to discuss and consult with the company/ investors about what they want from the results of the release of customary land of nagari intended to be used as oil palm plantations.

Broadly speaking, granting and registration of usufructuary rights for palm oil plantations in Nagari Inderapura through the following process:

1. Negotiations between PT Incasi Raya Group and ninik mamak/ leader of Nagari Indigenous Representative (KAN) of Inderapura that this area has the potential to become an oil palm plantation;

2. PT Incasi Raya Group notified its wishes to the Pesisir Selatan Regency government;

3. The government releases the customary land originating from customary people to be released into state land, in this case represented by ninik mamak as the top of the customary leader in the area;

4. The form and amount of compensation or siliahjarih payment is deliberated between ninik mamak and PT Incasi Raya Group under the supervision of the Pesisir Selatan Regency government, bearing in mind that the provisions of Article 12 of Law No. 39 of 2014 concerning plantations.

5. After the compensation or siliahjariah payment was agreed, PT Incasi Raya Group was given permission to open land for oil palm plantation and as the ruler of the nagari customary land, ninik mamak handed over the nagari customary land to the local government.

6. Subsequently, the Head of the National Land Affairs issued a usufructuary rights decision to PT Incasi Raya.

As specified in Article 50 paragraph (2) of the Basic Agrarian Law, further regulations regarding land that can be granted with usufructuary rights, can be found in Government Regulation No. 40 of 1996. In the formulation of Article 4, Government Regulation No. 40 of 1996 concerning Usufructuary Rights, Right to Build and Usufructuary Rights mentioned: 
1. Land that can be granted with usufructuary rights is state land.

2. In the case that the granting of usufructuary rights is state land which is a forest area, granting usufructuary rights can be carried out after the land is removed from its status as a forest area.

3. In the case of usufructuary rights granting of land that has been controlled with certain rights in accordance with applicable provisions, the implementation of usufructuary rights provisions can only be carried out after the release of the said rights is completed in accordance with the procedures set out in the applicable laws and regulations.

4. In the case on land that will be granted with usufructuary rights there are plants and/ or buildings owned by other parties whose existence is based on legal rights, the owner of the building and plants are compensated for the costs charged to new usufructuary rights holders.

5. Further provisions regarding granting compensation as referred to in paragraph (4), are determined by Presidential Decree.

As with other land rights, usufructuary rights must also be registered as explained in Article 32, Law No. 5 of 1960 concerning the Basic Rules of Agrarian Principles as follows:

1. Usufructuary rights, including the terms of the granting and also any transfer and abolition of such rights, must be registered according to the provisions referred to in article 19.

2. The registration referred to in paragraph 1 is a strong means of proving the transfer and abolition of usufructuary rights, except in the case that the rights are deleted because the time period expires.

In the case of granting land rights permits that will be used for usufructuary rights, Regulation of the Head of the National Land Agency No. 2 of 2013 concerning the Delegation of Usufructuary Granting Authority Rights and Land Registration Activities states:

\section{Article 8:}

"The Head of the Regional Office of the National Land Agency gave a decision regarding the granting of Usufructuary rights to land with an area of no more than 2,000,000 $\mathrm{M}^{2}$ (two million square meters)."

Article 13:

"The Head of the National Land Agency of the Republic of Indonesia gives a decision regarding granting of land rights that have not been delegated authority to the Head of the Regional Office of the National Land Agency or the Head of the Land Office".

Based on the two formulations of the Article above, Article 8 and Article 13, it was stated that the granting of usufructuary rights can be carried out up to an area of 2,000,000 $\mathrm{M}^{2}$ (two million square meters) or 200 hectares, usufructuary granting rights carried out by the Head of the Regional Office of the Provincial Land Agency and starting 2,000,000 $\mathrm{M}^{2}$ (two million square meters) or 200 hectares or more, granting usufructuary rights carried out by the Head of the National Land Agency/ Minister of Agrarian Affairs.

Usufructuary rights occur with a request for usufructuary rights granting by the applicant to the Head of the Republic of Indonesia's National Land Affairs. Granting of usufructuary rights must be registered in the land book at the land office. The granting of usufructuary rights can only be made based 
on a Government Decree through an authorized official on land which is state-controlled land and has not been granted another right to another party. Since granting usufructuary rights is included in something different in the public field, the registration of granting of usufructuary rights is also a determination at the birth of the usufructuary rights.

Without such registration, usufructuary rights never existed at all. This is in accordance with the theory of legal protection that the interests of human rights and interests need to be regulated and need to be protected. In addition, the law aims to integrate and coordinate various interests because in a traffic of interests, the protection of certain interests can be carried out by slaughtering various interests on the other hand. So, by granting and registering usufructuary rights for oil palm plantations the company has obtained legal protection. legal protection is a protection that is given to legal subjects in accordance with the rules of law that are preventive or repressive and written or unwritten in order to enforce the legal regulations to run the plantation business.

However, in the case of granting and registration of usufructuary rights of oil palm plantations originating from customary land as mandated by law, the ninik mamak, customary people, ulama, smart outriggers and the Pesisir Selatan Regency Government in matters that become the frontline in safeguarding the rights of people who are weak in the thought and knowledge of the use of customary land, should be the last bastion in providing knowledge about the use of customary land as described in Article 3, Regional Regulation of West Sumatra No. 6 of 2008 concerning Customary Land and Utilization which states:

1. The main target of the use of customary land is to improve the welfare and prosperity of customary people;

2. Utilization of customary land by other parties who are not citizens of the customary law people concerned is carried out on the principle of mutual benefit and risk sharing with the custom of "diisi limbago dituang" method as stipulated by consensus;

3. If the customary land is no longer utilized by the management of legal entities and/ or other individuals, the land returns to the authorities or the original customary land owner, with due regard to the relevant civil rights related to the customary land.

As stated in Law No. 39 of 2014 concerning Plantations and Article 58 paragraph (1), plantation companies that have plantation business permits or plantation business permits for cultivation are required to facilitate community-owned estates of at least $20 \%$ of the total plantation area proposed by plantation companies. In accordance with the aim of agrarian reform to reduce inequality in land tenure and ownership in order to create justice and deal with agrarian disputes and conflicts. It also requires land redistribution. Land redistribution is the distribution of lands controlled by the state and has been confirmed to be the object of land reform given to smallholder farmers who have fulfilled the requirements aimed at improving the socioeconomic condition of the community, especially farmers, by carrying out a fair and equitable distribution of land over resources. the livelihood of the farming community in the form of land. Thus, the granting can achieve equitable and equitable sharing of results. 


\section{Conclusions}

1. The granting of an oil palm plantation business permit occurs with the approval in principle of an oil palm plantation cultivation business and the application for a location permit based on the decision of the Head of the Pesisir Selatan Regency Land Office as well as a letter from the Governor of West Sumatra Provincial Level I Governor regarding Licensing for Land Opening for the Oil Palm Plantation Business in Nagari Inderapura . The process of approval in principle and licensing of palm oil plantation cultivation business location for the first time occurred in Inderapura in 1997. In this agreement, the company should provide plasma-core land because it is also the right of local customary people where the company/ investor carries out its business activities. In theory of rights, the rights of local customary people have not yet been fulfilled in the absence of the opening of plasma-core lands for people. In this case, rights are something inherent in humans in physical aspects as well as their existential aspects.

2. The release of customary rights for the oil palm plantation business in Inderapura to date with a total land acquisition of usufructuary rights of $\pm 11,930$ hectares with payment of silihjariah money using the custom of "diisi limbago dituang" method through consensus agreement. The handover took place in three phases: first in 1997 with $\pm 6,760$ hectares, second in 2005 with \pm 4,600 hectares and third in 2017 with \pm 570 hectares. In the absence of an agreement to provide plasma land, ninik mamak/ leaders and several community leaders in 1999 made demands to fulfill the existence of core plasma whose land was provided by Inderapura people along with the work of the nucleus estate. Then an agreement was made stating that the company was willing to implement a core plasma plantation with an area of $\pm 3,000$ hectares in which the memorandum of agreement was re-edited in 2005 where the land area was changed to 2,000 hectares and 1,000 hectares was excluded from the core plasma plantation development program and willing to make their own smallholdings by getting credit for oil palm seeds ready for planting from companies with a credit pattern through commercial credit through state-owned banks. Inderapura's Relatives, related to the information on the excess customary land of Nagari Inderapura in 2017 with a total area of 570 hectares of customary land, made demands for the land so that it can be used or reused. In this case, the land has produced oil palm on the company's core land.

3. Granting and registration of usufructuary rights for oil palm plantation occurred because of the request for granting usufructuary rights by the applicant to the Head of the Republic of Indonesia's National Land Affairs in 1997. Registration of usufructuary rights must be registered in the land book at the land office. The granting and registration of usufructuary rights can only be carried out based on a Government Decree through an authorized official on state land which is state-controlled land and has not been granted other land rights to another party. Since granting of usufructuary rights is included in something different in the public field, registration of granting of usufructuary rights is also a determination of the birth of usufructuary rights. Without such registration, usufructuary rights never existed at all. 


\section{References}

\section{Journal:}

Kurnia Warman, Agrarian Law in Compound People: The Dynamics of Interaction of Customary Law and State Law in West Sumatra, HuMa, Jakarta, 2010, page 39.

Fay, C., \& Sirait, M. (2005). Kerangka hukum negara dalam mengatur agraria dan kehutanan Indonesia: Mempertanyakan sistem ganda kewenangan atas penguasaan tanah (Vol. 3). ICRAF Southeast Asia Working Paper.

Tegnan, H. (2015). Legal pluralism and land administration in West Sumatra: the implementation of the regulations of both local and nagari governments on communal land tenure. The Journal of Legal Pluralism and Unofficial Law, 47(2), 312-323.

von Benda-Beckmann, F., \& von Benda-Beckmann, K. (2013). Political and legal transformations of an Indonesian polity: the Nagari from colonisation to decentralisation. Cambridge University Press.

Wibowo, Y. (2016). Analisis Prospektif Strategi Pengembangan Daya Saing Perusahaan Daerah Perkebunan. AGROINTEK, 4(2), 104-113.

Vel, J. A., \& Bedner, A. W. (2015). Decentralisation and village governance in Indonesia: the return to the nagari and the 2014 Village Law. The Journal of Legal Pluralism and Unofficial Law, 47(3), 493-507.

\section{Legislations:}

The 1945 Constitution of the Republic of Indonesia

Law No. 5 of 1960 concerning Basic Rules of Agrarian Principles

Law No. 18 of 2004 concerning Plantations (Revoked)

Law No. 39 of 2014 concerning Plantations (Latest)

Government Regulation No. 24 of 1997 concerning Land Registration

Government Regulation No. 40 of 1996 concerning Usufructuary Rights, Building Use Rights and Land Use Rights

Republic of Indonesia Presidential Regulation No. 86 of 2018 concerning Agrarian Reform

Minister of Agriculture Regulation No. 5 of 2019 concerning Procedures for Licensing in the Agriculture Sector

Regulation of the Head of the Land Agency No. 10 of 2016 concerning Procedures for Establishing Communal Rights in Land of Customary Law People and People in Certain Areas

Regulation of the Head of the Land Agency No. 5 of 1999 concerning Guidelines for Resolving Problems of the Customary Rights of Customary Law People

West Sumatra Regional Regulation No. 6 of 2008 concerning Customary Land and Its Utilization 
West Sumatra Governor Regulation No. 21 of 2012 concerning Guidelines and Procedures for Utilizing Customary Land for Investment

\section{Copyrights}

Copyright for this article is retained by the author(s), with first publication rights granted to the journal.

This is an open-access article distributed under the terms and conditions of the Creative Commons Attribution license (http://creativecommons.org/licenses/by/4.0/). 